\title{
Land Management Strategies and their Implications for Mazahua Farmers' Livelihoods in the Highlands of Central Mexico
}

Abstract

This paper presents a case study from a Mazahua indigenous community in the rural Highlands of Central Mexico. It analyses Mazahua farming livelihoods characterised by subsistence agriculture, marginality, poverty and severe land degradation. Mazahua farmers face constrained environmental, socioeconomic and cultural conditions, which influence describe the capital assets base used, where land, livestock and crop production are imperative assets to support farmers' livelihood strategies. It analyses local management practices to achieve livelihood outcomes in the short/ long term, and to improve or undermine land characteristics and other related assets. It also presents a farmer typology constructed by local perceptions, a controversial element to drive sustainable development strategies at the local level. Finally, it discusses how local land management practices are adopted and their importance in developing alternatives to encourage positive trade-offs between conservation and production in order to improve rural livelihoods.

Keywords

Rural livelihoods • Mazahua farmers • hillside areas

(C) University of Warsaw - Faculty of Geography and Regional Studies their local decisions on natural resource management. The results

\author{
Belina García-Fajardo ${ }^{1}$ \\ María Estela Orozco-Hernández ${ }^{2}$, John McDonagh ${ }^{3}$ \\ Gustavo Álvarez-Arteaga ${ }^{4}$, Patricia Mireles-Lezama $^{5}$ \\ ${ }^{1}$ Facultad de Planeación Urbana y Regional, Universidad \\ Autónoma del Estado de México, México \\ e-mail: belygf@gmail.com \\ ${ }^{2}$ Facultad de Planeación Urbana y Regional, Universidad \\ Autónoma del Estado de México, México \\ e-mail: eorozcoh61@hotmail.com \\ ${ }^{3}$ School of International Development, University of East \\ Anglia, Norwich, United Kingdom \\ e-mail: jmcdonagh@uea.ac.uk \\ ${ }^{4}$ Facultad de Planeación Urbana y Regional, Universidad \\ Autónoma del Estado de México, México \\ Facultad de Ciencias, Universidad Nacional Autónoma de \\ México, México. \\ e-mail: galvareza68@gmail.com \\ ${ }^{5}$ Facultad de Planeación Urbana y Regional, Universidad \\ Autónoma del Estado de México, México \\ e-mail:paty_land@hotmail.com \\ Received: 16 March 2015 \\ Accepted: 7 January 2016
}

Introduction

Environmental degradation, particularly of land resources, is one of the most important problems affecting farming highlands, due to steep slopes, high vulnerability and suggested overexploitation of scarce natural resources (Blaikie \& Brookfield 1987, Becerra 1998, Amsalu 2006, Amsalu \& DeGraff 2006). Therefore, highlands are a primary target of conservation measures because of the perceived relationship between cultivation practices, poverty and land degradation (Lestrelin \& Giordano 2007).

The Highlands of Central Mexico is a place of integration, changes and conservation for different cultures, including mestizo and minority indigenous groups like Mazahuas, who have built their principal settlements here. The multicultural context of the highlands influences local farmers' strategies such as traditional, indigenous and promoted land management, all of which are intertwined in the current farming systems (Anaya-Garduño 2003; Hudson \& Alcántara-Ayala 2006; Sommer et al 2007). Poverty and challenging socioeconomic and environmental conditions are common in Mazahua rural farming communities. The soil loss estimation in maize agricultural units of production in sloping areas of the region is approximately 130 ton/ha/year (García-Fajardo, 2002). This drives farmers to develop diverse natural resource management and makes them willing to innovate in order to survive (Brookfield et al 2002; Stocking 2002). Diversity and complexity are reflected in the different ways local farmers transform their existing resources.

Local responses and knowledge are central to building paths to reverse or control environmental degradation, particularly of land. Therefore, local land users are a major asset in reversing the trend towards degradation in the highlands (Eswaran et al 2001), as well as enhancing sustainable land management and improving their farming livelihoods. Identification of local practices adopted in agricultural areas, how assets are used, and the different ways in which local users feel they benefit or lose from their management is key to sustainable land management. A common vision of how best to interact with the environment in constrained contexts is seen in farming livelihoods. A better understanding of people's rural livelihoods, their agricultural processes and other related resource management is required in order to explain how their actions have impacts at the local and regional level. This helps to identify land users' allocation of their own resources and explores local attitudes, perceptions and rationales of technology adoption for land management.

This paper aims to provide an understanding of both the land management and the conservation actions adopted in agricultural units of production by Mazahua farmers as part of their livelihood strategies and the implications for their livelihoods in a selected case study. In order to achieve this, it characterises Mazahua farming livelihoods and the historical and physical context. It also describes land uses and soil types at the local level where households have established their farming livelihoods. Later, it enlists land management technologies adopted by farmers; it explores the gains and costs of the adoption of technologies consistent with households' capital assets. An appraisal of technologies by farmers is core to recognising their views on how technologies impact their capital assets and livelihoods these are presented in pentagon diagrams. Next, rural farming households are classified by using two criteria: a wealth proxy and a local farmer's typology, both based on local perceptions. 


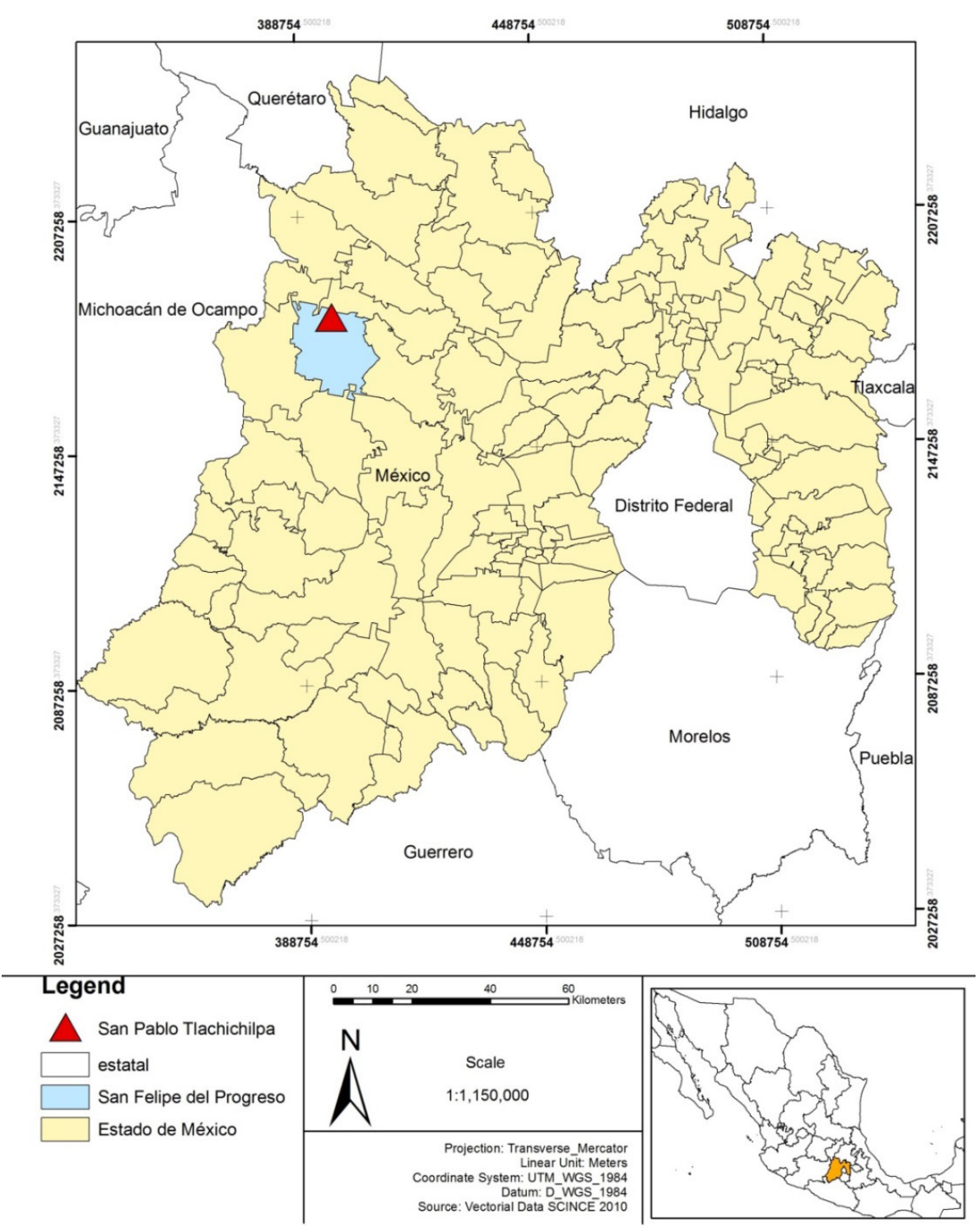

Figure 1. Case study location

This recognises households' differing access to assets. Finally, the paper associates household wealth types with farmers' local typology and with land management practice groups in order to explain the decision-making process on land management and its implications for households' assets and rural livelihoods.

\section{Methodology}

A case study approach in a farming agricultural community was employed in order to engage mixed methods of data collection (qualitative and quantitative) based on a holistic approach. To describe the local context, a survey to collect data on socio-demographics and general land management was conducted. It characterized 101 farming households' livelihoods and adoption of land management practices within 291 units of productions. In addition, in-depth interviews were carried out with expert farmers and focus groups during the farming period to explain decision-making processes regarding land management strategies.
Mazahua farming livelihoods

The Mazahua indigenous group is one of the biggest in the Highlands of Central Mexico. It is located in the Northwest part of the State of Mexico. The Mazahua group incorporates indigenous, Spanish and mestizo practices that have shaped the development of their society. Subsistence rain-fed agriculture employing limited household labour, maize cultivation, agave hedgerows, livestock, strong social capital, traditional task division, land attachment, patriarchal traditions and migration are significant characteristics of the Mazahua communities (Soustelle 1993; Nava-Bernal 2003; Chávez Mejía 2007).

The case study was carried out in the community of San Pablo Tlachichilpa (SPT), located in the municipality of San Felipe del Progreso, State of Mexico (see Figure 1). This municipality is one of the poorest in this state (Blanquel \& Hernández 1999, Cotler \& Ortega-Larrocea 2006). Hence, SPT is characterised by poverty and marginality. The community has a population of 3838 people (INEGI 2010), both indigenous and mestizos. 
Mazahua livelihoods and agricultural land

The case study is representative for traditional rain-fed subsistence agriculture systems in Central Mexico. Farmers' arable land holdings range from 0.25 ha to 10 ha per household (Arriaga-Jordán et al 2005; García Fajardo 2011) at altitudes between 2760 and 2870 metres above sea level. Farmers manage private, ejido or communal property with different land uses. As noted by Chávez Mejía (2001), solar (home garden), milpa (maize plots), bosque (forest), pradera (grassland) and limites (edges) are the land use types managed in San Pablo. Milpa and solar constitute the main agricultural land in the area and it is here that responses to land management practices take place the most (Chavez et al 2002).

Maize, beans and oats are the staple crops cultivated by farmers in the SPT community. According to the survey, the mean maize production is 1.94 ton/ha, although this varies considerably between units of production and depends on inorganic fertiliser inputs. Agricultural activities are carried out in water-restricted conditions because they rely on rainfall for crop production. Water availability is limited to $800 \mathrm{~mm}$ of rainfall per year between May and September (temperate sub-humid climate). This increases the vulnerability of crops to climate variability. Water availability is an important issue and may drive farmers' decisions on land management. Thus, land management decisions will focus on implementing practices which help to maintain and/or increase soil moisture or water availability to crops and improve maize production. Farmers highlight frosts and severe droughts as the main threats to crops and point out that intense rain and strong winds can also cause considerable damage to their crops (GarcíaFajardo, 2002)

Agricultural units of production are vulnerable to land degradation processes because of the community's mixed topography of valleys and hills (see Figure 2) - in particular, soil erosion on the steep slopes (15 to 35 per cent) in andosols and lithosols. Soil erosion intensified due to land use changes through deforestation activities in the 19th century. This led to the widespread occurrence of gullies and sheet erosion in the community, which are visually observable in the landscape (see Figure 3).

The increase in the migration of young people to urban areas affects farming livelihoods, especially since agricultural activities and natural resource management rely on family labour and social networks (Nava-Bernal 2003). Migration has led to changes in labour availability, farming tasks, types of crops, land management actions and social capital.

\section{Soil types}

Chávez Mejía (2007) points out that local soil classification is comprehensive and complex, as there are different combinations of soils, reflecting the diversity of the soil's attributes (BarreraBassols et al 2006). The classification of soils is generalised into six major soil types as recognized by farmers: arena (sand), pejo (clay), colorada (red), polvilla (dust), tepetate (duripan) and negra (black) (see Figure 4). Water erosion and tectonic movements have modified the exposure of the soil types by bringing them to the surface or burying them, as identified in Figure 4 by an expert farmer in SPT.

\section{Land management and livelihood assets}

Farmers notice that gullies affect some units of production, especially decreasing the area for cultivation, and they have also recognised sheet and rill erosion occurring in their plots. This has pushed them to make individualistic decisions on land management, each land user tailoring and adopting technologies according to each field's specific needs, local soil knowledge and resource availability (Kessler, 2006; Okoba, B., De Graff, J., 2005).

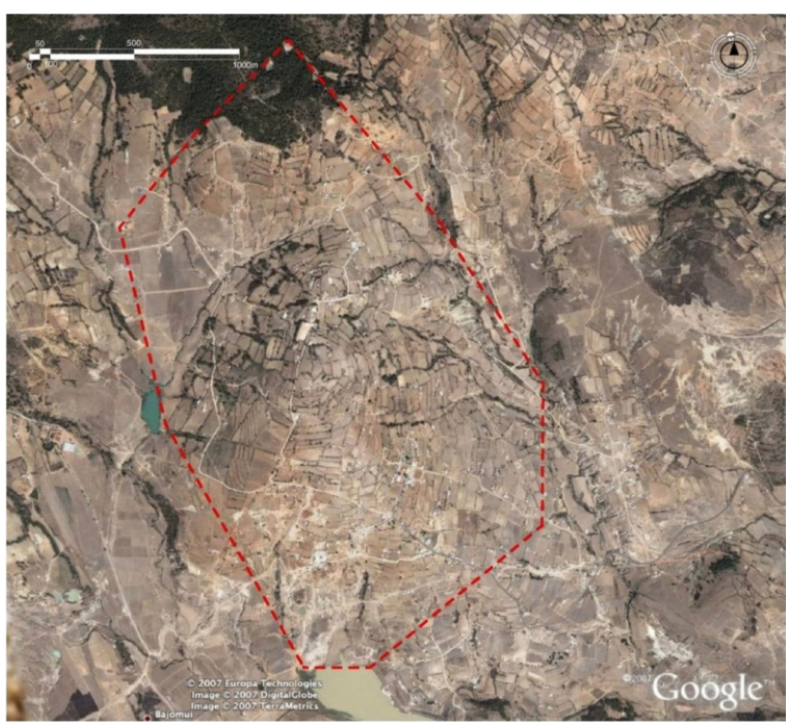

Figure 2. Landscape of study area of San Pablo Tlachichilpa Source: García Fajardo (2011)

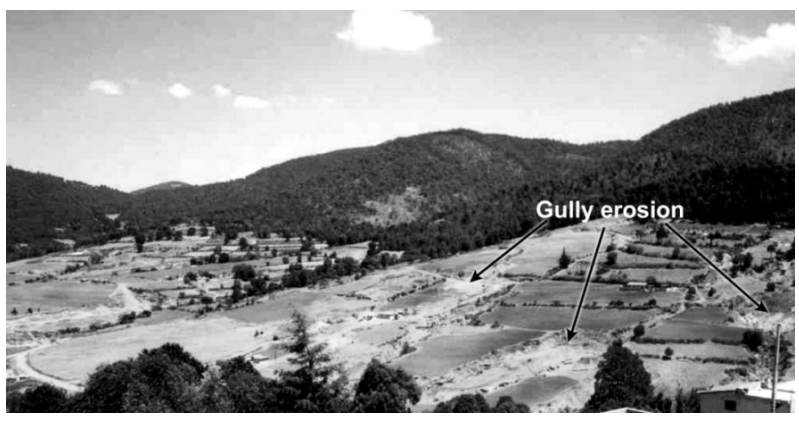

Figure 3. Land degradation in a sector of San Pablo Tlachichilpa Source: García Fajardo (2011)

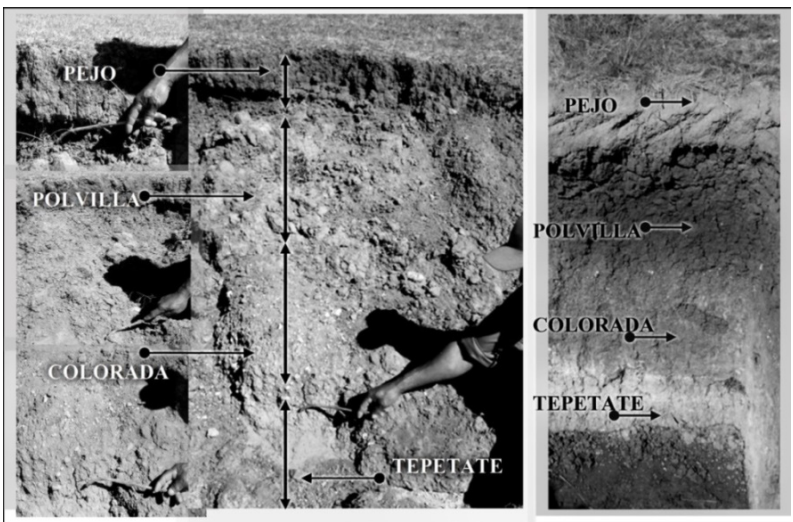

Figure 4. Soil types identified by an expert farmer in SPT Source: García Fajardo $(2011,101)$

All these elements may manifest in their practices. According to the survey, farmers in the community adopt 17 different land management technologies. From the local perspective, the practices contribute to reducing or controlling (directly or indirectly) land degradation (see Table 1). 
Table 1. Land management technologies adopted by famers in the case study

\begin{tabular}{|c|c|c|}
\hline \multicolumn{3}{|c|}{ TECHNOLOGY'S MAIN PURPOSE TECHNOLOGY NAME } \\
\hline \multirow{7}{*}{ Soil erosion control } & $\bullet$ & Hole \\
\hline & • & Ditch \\
\hline & $\bullet$ & Mid-field earth bunds \\
\hline & • & Tied-ridges \\
\hline & $\bullet$ & Furrow design \\
\hline & • & Stone Wall \\
\hline & • & Boundary vegetation \\
\hline \multirow{9}{*}{ Fertility management } & $\bullet$ & Arena-pumice incorporation \\
\hline & $\bullet$ & Weeding \\
\hline & • & Fodder residue mulching \\
\hline & • & Manure \\
\hline & • & Fertiliser \\
\hline & - & Intercropping \\
\hline & $\bullet$ & Crop rotation \\
\hline & • & Fallow \\
\hline & • & $\begin{array}{l}\text { Sediment incorporation } \\
\text { (Reinstating sediments) }\end{array}$ \\
\hline Area & $\bullet$ & Filling in gullies \\
\hline
\end{tabular}

The table shows the diverse ways that farmers take care of the land and solve the problems of land environmental degradation. These practices are combined or used individually and are designed to generate benefits simultaneously or on different terms, depending on asset availability and household interests. Any decision taken on land management has impacts on farmers' livelihood assets.

The array of technologies adopted in the community demands the combination of different capital assets - Natural, Human, Physical, Social, and Financial - which constitute the core of the livelihoods framework (Carney, 1999; Ellis, 2000). Farmers (adopters and non-adopters) assessed the 17 land management practices in relation to the values associated with the capital assets needed or gained through the adoption of each technology (García Fajardo, 2011). This assessment exposes farmers' preferences and perceptions on how they benefit or lose from specific land management practices. Assets are often displayed in a 'pentagon' as a visual presentation which enables an understanding of the important inter-relationships between the various assets and how they combine with one another build livelihoods (DFID 1999, 2004). Figure 5 shows pentagons of the overall values given to land management practices per capital assets, as appraised by farmers.

The below figure provides a broad picture of how technologies are linked to, or how they affect, capital assets, based on farmers' own evaluations. The fertiliser pentagon provides evidence of farmers' awareness of the limited contribution of applying fertilisers to improve or manage natural, human or physical assets. Its values are associated with impacts on fertility, crop production, and above all on social aspects, such as customs/ traditions and networks. In contrast, farmers perceive the

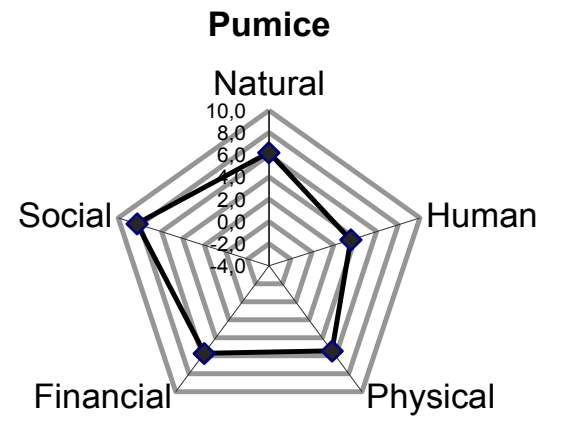

Financial Physical

\section{Fertiliser}

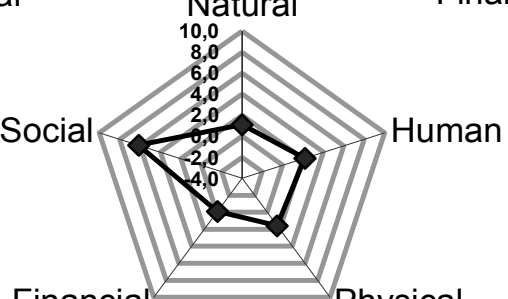

\section{B. vegetation}

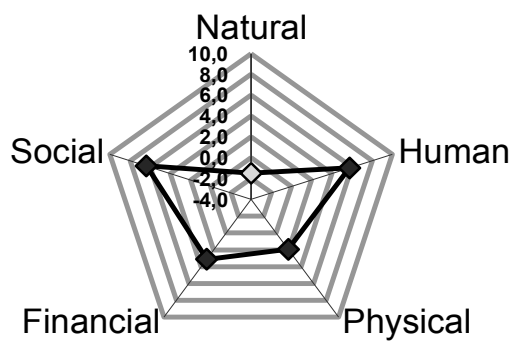

Stonewall

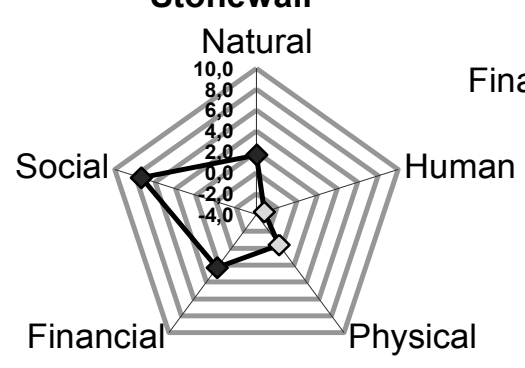

Fallow

ical

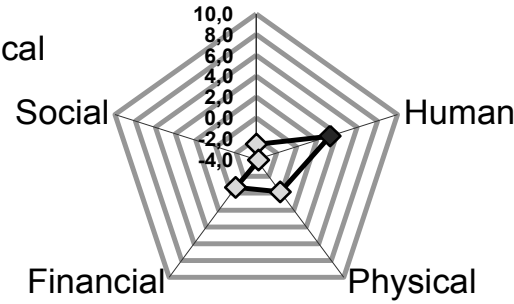

Figure 5. Values given to land management practices by farmers in relation to their impacts on households' capitals Source: García Fajardo $(2011,188)$ 
Table 2. Characterization of farmers based on their land management

\begin{tabular}{|c|c|c|c|}
\hline & \multicolumn{3}{|c|}{ Farmer Type } \\
\hline & The "good/expert" farmer & The "mad" farmer & The "lazy" farmer \\
\hline $\begin{array}{c}\text { General } \\
\text { characteristics }\end{array}$ & $\begin{array}{l}\text {-Hard-working, networkers, status- } \\
\text { conscious, follow instructions, } \\
\text { community-minded, bilingual } \\
\text { (Spanish/Mazahua), migrant } \\
\text { children, old farmers, illiterate, } \\
\text { proud of livestock ownership, like } \\
\text { experimentation, like traditions and } \\
\text { challenges, active political and } \\
\text { religious life. Sell maize. }\end{array}$ & $\begin{array}{l}\text {-Eccentric, hard-working, individual } \\
\text { choice, off-farm/non-farm activities, } \\
\text { childless and labour-poor, have the } \\
\text { luxury to take risks as household } \\
\text { does not depend completely on land, } \\
\text { returning migrants or married to } \\
\text { outsiders, confident, bilingual (Spanish } \\
\text { and Mazahua), illiterate. Produce } \\
\text { enough maize for own consumption } \\
\text { and livestock forage. Business- } \\
\text { minded. }\end{array}$ & $\begin{array}{l}\text {-Outward-looking, extremely } \\
\text { opportunistic, land-poor, young } \\
\text { adults, migrant, risk-adverse, } \\
\text { follow tradition, household } \\
\text { depends on off-farm activities, } \\
\text { buy maize, hire labour to adopt } \\
\text { technologies, speak Spanish and } \\
\text { understands Mazahua, literate } \\
\text { (primary school). }\end{array}$ \\
\hline $\begin{array}{c}\text { How the } \\
\text { farmers are } \\
\text { seen by } \\
\text { others in the } \\
\text { community }\end{array}$ & $\begin{array}{c}\text { If you want to see a well- protected } \\
\text { and cultivated plot, go and look at } \\
\text { their land. They are hard-working, } \\
\text { nosy, good people. They are old } \\
\text { and experienced in farming, and } \\
\text { have time to look after their land. } \\
\text { Their milpas are really good, no } \\
\text { weeds, no water eroding the land, } \\
\text { nice maize cobs. They like working } \\
\text { with others. }\end{array}$ & $\begin{array}{c}\text { They are hard-working. They are mad; } \\
\text { nobody does what they do. They don't } \\
\text { follow traditions, but their ideas work. A } \\
\text { different way of working land, but other } \\
\text { farmers are not interested. They are } \\
\text { weird. Nobody likes that way, except } \\
\text { them. }\end{array}$ & $\begin{array}{l}\text { They're lazy and don't want to do } \\
\text { weeding, or dig a hole or ditch. } \\
\text { They are young. Her husband is a } \\
\text { migrant so she does not know how } \\
\text { to look after her land. Their milpas } \\
\text { have lots of weeds; that's why } \\
\text { they don't have good maize. They } \\
\text { aren't interested in land. They like } \\
\text { drinking and partying. They have } \\
\text { to buy maize and that is not good. }\end{array}$ \\
\hline
\end{tabular}

Source: adapted from García Fajardo $(2011,248)$

incorporation of pumice (volcanic white sand) into their land as having a positive impact on different capitals. This practice helps to improve land moisture, brings social recognition and has a low demand on financial and physical assets. However, pumice incorporation is regarded as an intense investment practice (high labour and time needed for its adoption), as reflected in the low human capital asset scores. The boundary vegetation pentagon has positive values in most capital types except natural assets, as plants compete for space, soil moisture and nutrients. Fallow shows negatives scores in four capital assets, farmers believing that keeping land fallow is detrimental to soil moisture due to long periods of exposure to climatic conditions without the protection of crops. The lack of moisture makes the land very difficult to till. As access to land for cultivation is limited, fallow is characteristic of a land user who does not manage land properly or is lazy, which is not well viewed in the community, hence the lowest scores for its social assets.

\section{Farmers' typologies and livelihood assets}

Households in rural farming communities have different access to assets. Households in the community are classified by two criteria: 1) a wealth proxy, using their local perceptions and characterisation from the survey, and 2) a local farmer's typology, referring to the way they work or manage their agricultural land by using their own local expression and perceptions. The first criterion, the wealth proxy, is based on farmers' points of view about what constitutes a rich household. Farmers indicate richness in terms of ownership of "good land" (productive soil types), livestock, and maize crop production to sell. This concept of wealth is based on local perceptions, which may differ from a more formal economic measure of wealth. In the local context, land, livestock ownership and crop production are needed to develop farming household livelihoods and are strongly linked to decisions on land management strategies. Thus, these are chosen as the criteria to develop a wealth ranking (rich, medium and poor households) which is in accord with farmers' views. ${ }^{1}$

According to this wealth ranking, rich families in SPT present secure land tenure, high land productivity (good soil fertility), and variable number of livestock heads. The socioeconomic features indicate that heads of households have low levels of education as they are generally old people (no access to formal education in the past). In general, these families are self-sufficient for food, with the option of extra income from the sale of grain and animals and with low labour availability. The medium-wealth families present a diversity of access to assets. A large number of the families interviewed were in this category. There is a remarkable variability in their assets, which may be driven by changes in livestock holdings or selling off land (assets commonly tradedoff). The poor families are not directly dependent on crop production due to their limited access to land and livestock. They are not self-sufficient and get their money from non-farm paid activities and received remittances. Contrastingly, the heads of poor family households have higher levels of education that the medium or rich ones.

The second criterion is a local farmer's typology; it is created from farmers' appreciations of how they work their land. According to the in-depth interviews, there are three main local expressions used by expert farmers which reveal differences in land management strategies: the "good" farmer (expert farmer), the "mad" farmer and the "lazy" farmer (translated from Spanish). These expressions are used in this typology to label farmer types. This conveys a local point of view and is not meant to be pejorative. Above Table 2 describes the general characteristics of each farmer type and presents quotations from local people in order to show how each farmer type is defined in the community.

${ }^{1}$ The methodology for determining the wealth proxy is detailed in García Fajardo 2011. 


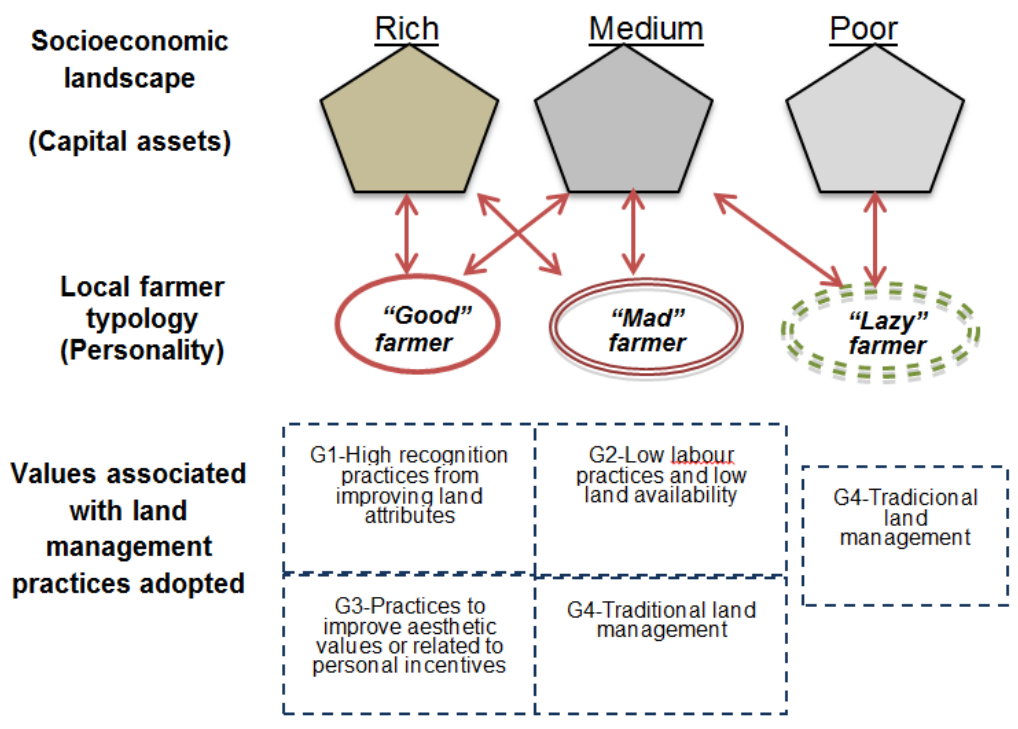

Figure 6. Farmer typologies and agricultural land management Source: adapted from García Fajardo $(2011,265)$

The "good" farmer type expresses the intrinsic values linked to agricultural activities, such as land affection, religious commitment and a sense of personal responsibility for the units of production and nature. Households satisfy their maize demand, which increases their social recognition and empowerment. Land degradation control practices are both a vision and a need as they are mainly dependent on agricultural production. "Good" farmers are involved in the political life of the community and in contact with external stakeholders constructing a strong social capital. The "mad" farmer type indicates farmers' difficulties in accessing land and labour, and the restricted networks in the community. This pushes them to demonstrate that the way they work the land is more profitable than the usual methods of land management. They diversify their livelihoods, securing their incomes with livestock ownership and commercialisation. Finally, "lazy" farmers are associated with constraints such as lack of land and they have to meet short-term household needs for education, clothing and food. Migration, off-farm activities, and lack of access to financial support for farming, as well as the lack of knowledge and experience of farming, undermine "lazy" farmers' attachment to the land. Their vision of land management is continuing with traditional activities without investing more, in order to produce part of their food.

The deconstruction of farmers' experiences in land management according to farmer typology is an engaging though perhaps questionable analytical exercise in enabling a qualitative approach to farming livelihoods. Nevertheless, both typologies provide a landscape of land users' attitudes and the perceptions central to promoting sustainable alternatives for resource use at the local level.

\section{Farmers, land management and agriculture}

Local land management strategies taken at the household level are related to the availability of, and access to, assets, and to intrinsic factors such as farming experiences, personal interest and cultural context. Therefore, the outcomes of farmers' decisions have a positive or negative impact on the land and related resources. Figure 6 provides a starting point to explain the decision making processes related to land management strategies in rural farming households.
This figure shows the socioeconomic landscape (capital assets) of rural farming households in SPT represented by the categorizations of wealth. It integrates this with farmer types (personality) and values associated with land management practices adopted at the local level by farming households. This provides a basic representation of how technologies are aggregated according to the characteristics of the adopting families. The land management is carried out in relation to specific household attributes, conditions of units of production and individual features. For instance, heads of rich and medium households are commonly regarded as the "good" or "mad" farmers. Their current assets base provides conditions enabling the adoption of specific practices, in addition to their intrinsic conditions, such as aspirations and personal goals. The latter also drive farmers' choices in land management. These households have more flexibility to take risks, such as changing crops or leaving land fallow (i.e. they are less risk-averse) due to greater access to the land.

As shown in Figure 6, "good" or "mad" farmers are able to adopt different groups of technologies, such as those from Group 1 (G1), which give them high recognition and improvement of land attributes, Group 2 (G2) technologies that demand low labour or low land availability, Group 3 (G3) practices related to aesthetics or personal values, and Group 4 (G4), which are traditional or standard land management practices.

The "good" or "mad" farmers carry out intensive investment technologies which require a large investment of labour, time and/or financial assets. These types of farmers are concerned with improving maize production on land prone to degradation or land that is already degraded. "Good/Expert" farmers whose units of production are affected by soil erosion processes (e.g. gully erosion) may adopt practices to tackle this problem in order to improve their land and/or to gain recognition from the community. Rich/medium or "good"/"mad" farmers may have the conditions to choose economic gains in the form of food security over other outputs in the short term. When farmers' needs for food security are met, social and individual factors, such as recognition, personal incentive to manage land, customs and traditions, aesthetic and social capital, may have a positive influence on enhancing their resources base (Sattler \& Nagel, 
2010). It is common that rich or "good" farmers cite technologies previously adopted because they still obtain benefits from these types of practices, which are relevant to their current livelihoods; they provide benefits in a long-term.

The "lazy" farmers are those who adopt common or "standard" agricultural and land practices (G4) in order to continue cultivating each year - the crop production helps them to meet food needs in the periods of lack of work when there is no income. This provokes the question of whether the "lazy" farmers are people not willing to work, or not able to work, due to their current conditions and availability of assets.

Livelihood decisions are regularly adjusted to socioeconomic, cultural and environmental changes. Farmers depending on subsistence agriculture, such as "good/expert" farmers, may prefer trade-offs to gain positive outcomes or at least to reduce negative trends in order to lessen the household's vulnerability (e.g. positive outcomes encourage decreasing abandonment of units of production, improving soil properties to increase maize yields in the long term, making agriculture an appealing livelihood to their children). However, the pressure from political and economic contexts is pushing all types of farmers to favour increasing production via the use of fertilisers and herbicides, monoculture and less fallow, which needs to be addressed (IDB, 2010).

In constrained environments, an understanding of the local decision making processes in land management is essential to inform the future direction of technical and policy interventions seeking to improve land use and rural farming livelihoods. This is particularly relevant as external stakeholders tend to have their own normative views and criteria when implementing projects in communities, generally selecting "good" farmers or in some cases "mad" ones, while ignoring "lazy" farmers. According to this view, local perceptions may themselves be seen as operational standpoints in order to avoid the exclusion of particular groups of farmers and to include those individuals who are often the poorer and less socially-advantaged in the communities.

\section{Conclusions}

Land management practices involved asset trade-offs because of direct interactions between farming households and their environments. In the end, land management decisions come down to farmers' choices embedded in asset availability and intrinsic perspectives. The farmers' own perceptions presented in a provocative typology could lead to exciting implications for the potential design of land management interventions. Qualitative categorizations allow the recognition of land users' experiences, knowledge and interests and the effects of policy changes on land management decisions, in this case, in farming land management, without excluding the very important role of individual preferences. Technology promotion would be addressed to target specific group characteristics to encourage the success of projects. Consequently, environmental and development tasks should consider not only the natural resource management that is currently used and accepted by land users, but also individual farmer characteristics as perceived and categorised by the farming community itself.

\section{Acknowledgement}

We would like to thank the Research Project PROMEP "Estimación de almacenes de carbono en suelos bajo diferentes sistemas de producción agrícola en el Altiplanicie Mexicano" and CEPLAT- FaPUR for their sponsorship to attend the Zwierzyniec 2014 International Symposium on Sustainable Rural Development in Peripheral Regions, where this work was presented.

\section{References}

Amsalu, AT \& De Graaff, J 2006, 'Farmers' views of soil erosion problems and their conservation knowledge at Beressa Watershed, Central Highlands of Ethiopia', Agriculture and Human Values, issue 23, pp. 99-108.

Amsalu, AT \& De Graaff, J 2007, 'Determinants of adoption and continued use of stone terraces for soil and water conservation in an Ethiopian Highland watershed', Ecological Economics, issue 61, pp. 294-302.

Amsalu, AT 2006, Caring for the land: best practices in soil and water conservation in Beressa watershed, highlands of Ethiopia, Wageningen, Wageningen University.

Anaya Garduño, M 2003, La desertificación en México. Lineamientos estratégicos para su prevención y control, Zacatecas, México.

Arriaga-Jordán, CM, Pedraza-Fuentes, AM, Nava-Bernal, EG, Chávez-Mejía, MC \& Castelán-Ortega, OA 2005, 'Livestock agrodiversity of Mazahua smallholder campesino systems in the Highlands of Central Mexico', Human Ecology, issue 33, pp. 821-845.

Barrera-Bassols, N, Zinck, JA \& Van Ranst, E 2006, 'Symbolism, knowledge and management of soil and land resources in indigenous communities: Ethnopedology at global, regional and local scales,' CATENA, issue 65, pp. 118-137.

Becerra, A 1998, Conservación de Suelos y Desarrollo Sustentable, ¿Utopía o Posibilidad en México? Soil Conservation and Sustainable Development, Utopia or Possibility in Mexico?. Departamento de Suelos, Universidad Autnónoma Chapingo.

Blaikie, P \& Brookfield, H 1987, Land degradation and Societ, London, Methuen.
Blanquel, M \& Hernández, R 1999, San Felipe del Progreso. Monografía municipal, México, GOBIERNO DEL ESTADO DE MÉXICO-AMECROM.

Brookfield, H, Padoch, C, Parson, H \& Stocking, M 2002, Cultivating biodiversity: Understanding, analysing and using agricultural diversity, London, ITDG-UNU/UNEP-GEF.

Carney, D 1999, Counting Assets. A framework for understading sustainable rural livelihoods, London, Overseas Development Institute.

Chávez Mejía, M 2007, The construction of landscape and conservation by the Mazahua of Mexico (Tesis de Doctorado), Norwich, School of Development Studies, University of East Anglia.

Chávez Mejía, M 2001, Analisis del solar familiar campesino como sitio de experimentación e innovación. Caso de estudio: San Felipe del Progreso, Estado de México. Toluca, Centro de Investigación en Ciencias Agropecuarias, Universidad Autónoma del Estado de México.

Chavez, C, Nava, B, Velazquez, L, Mireles, P, Nava, Y, Pedraza, M, García, B, Ruiz, K \& Arriaga, C 2002, Management of agrodiversity and sustainablec campesino agriculture on the hillslopes of the Highlands of Central Mexico, Tolua, UNUUAEMex.

Cotler, H \& Ortega-Larrocea, M 2006, 'Effects of land use on soil erosion in a tropical dry forest ecosystem, Chamela watershed, Mexico', Catena, issue 65, pp. 107-117.

DFID, 1999. Sustainable livelihoods guidance sheets, LONDON, Deparment for International Development-DFID.

DFID, 2004, On measures taken to support the implementation of the United Nations Convention to combat desertification with 
a particular focus on affected developing country parties in Africa, LONDON, Deparment for International development DFID.

Ellis, F 2000, Rural livelihoods and diversity in developing countries, Oxford, Oxford University Press.

Eswaran, H, Lal, R \& Reich, PF 2001, Land degradation. An overview, New Delhi, Oxford Press.

García Fajardo, B 2011, Land degradation in the Highlands of Central Mexico. How Mazahua farmers manage, value and trade-off their control technologies (Tesis de Doctorado), Norwich, School of International Development, University of East Anglia.

García-Fajardo, B 2002, Local soil conservation technologies and their role within farmers' rural livelihoods. A case study from the highlands of Central Mexico (M.Sc. thesis), Norwich, University of East Anglia.

Hudson, PF \& Alcántara-Ayala, I 2006, 'Ancient and modern perspectives on land degradation', CATENA, pp. 102106.

IDB, 2010. Procampo enters a Decisive phase in Mexico. Available from: <http://www.iadb.org/en/topics/developmenteffectiveness/procampo-enters-a-decisive-phase-in-mexico, 1263.html>. [6 December 2010].

INEGI, 2010, XI Censo General de Población y Vivienda. Tabuladores Básicos, México, INSTITUTO NACIONAL DE ESTADÍSTICA Y GEOGRAFÍA.

Kessler, CA 2006, 'Decisive key-factors influencing farm households' soil and water conservation investments', Applied Geography, issue 26, pp. 40-60.
Lestrelin, G \& Giordano, M 2007, Upland development policy, livelihood change and land degradation interactions from a Laotian village, Land Degradation \& Development, issue 18, pp. 55-76.

Nava-Bernal, EG 2003, Local maize varieties in Central Mexico: their management and contribution to campesinos' livelihoods (PhD Thesis), Norwich, School of Development Studies, University of East Anglia.

Okoba, B \& De Graff, J 2005, Farmers' knowledge and perceptions of soil erosion and conservation measures in the Central Highlands, Kenya, Land Degradation \& Development, pp. 475-487.

Sánchez-Colón, S 2004, Evaluation of human induced soil degradation in Mexico, México, SEMARNAT.

Sattler, C \& Nagel, U 2010, 'Factors affecting farmers' acceptance of conservation measures - a case study from north-eastern Germany', Land Use Policy, pp. 70-77.

Sommer, R, Wall, PC \& Govaerts, B 2007, 'Model-based assessment of maize cropping under conventional and conservation agriculture in Highland Mexico', Soil and Tillage Research, vol. 94, pp. 83-100.

Soustelle, J 1993, La Familia Otomí-Pame del México Central [The Otomi-Pame family of Central Mexico], México, Fondo de Cultura Internacional.

Stocking, M 2002, 'Land degradation', International Encyclopaedia of the Social and Behavioral Sciences, pp. 8242-8247. 